\title{
TITLE:
}

\section{INVERTEBRATE FAUNA OF THE INTERTIDAL ZONE OF THE TOKARA ISLANDS -VI. ALCYONARIA-}

\author{
$\operatorname{AUTHOR}(\mathrm{S})$ :
}

Utinomi, Huzio

\section{CITATION:}

Utinomi, Huzio. INVERTEBRATE FAUNA OF THE INTERTIDAL ZONE OF THE TOKARA ISLANDS -VI. ALCYONARIA-. PUBLICATIONS OF THE SETO MARINE BIOLOGICAL LABORATORY 1953, 3(2): 149-160

ISSUE DATE:

1953-12-20

URL:

http://hdl.handle.net/2433/174473

RIGHT: 


\title{
INVERTEBRATE FAUNA OF THE INTERTIDAL ZONE OF THE TOKARA ISLANDS
}

\author{
VI. ALCYONARIA ${ }^{122}$ \\ HUZIO UTINOMI \\ Seto Marine Biological Laboratory, Sirahama
}

With Plate VIII and 5 Text-figures

A small collection of Alcyonaria which Dr. T. Tokroka brought home from the Tokara Islands comprises only 8 species, including a species of Microspicularia apparently new to science. All these species, except a new one, are widespread throughout the warm Indo-West Pacjic area, but have not been previously recorded from the southern territories of Japan. The materials were collected by Dr. TokiokA along the coast of two islands Nakano-sima and Takara-zima in the Tokara group at low tide, and no gorgonarian was included in the collection. Yet this collection is enough to provide an evidence speak for the subtropical feature of the fauna of the islands.

\section{STOLONIFERA}

Family Clavulariidae HICKSON

\section{Clavularia inflata $\mathrm{SCHENK}$}

(Figs. 1, 2; PI. VIII, Figs. 1, 2)

Clavularia inflata SCHENK, 1896, p. 48, pl. III, figs. 24-26.

Clavularia inflata var. Iuzoniana MAY, 1900, p. 44, pl. I, fig. 4 \& pl. V, fig. 1a, b.

Hicksonia köllikeri DEAN, 1927, p. 115; THOMSON \& DEAN, 1931, p. 15, pl. XII, figs. 4-6 \& pl. XXII, fig. 9.

Clavularia inflata var. luzoniana ROXAS, 1933a, p. 58; MACFADYEN, 1936, p. 24.

Jap. Name. Tutu-umizuta (nom. nov.).

Material. Numerous colonies from Nakano-sima, at low tide (TK. Nos. 55-56). ${ }^{3}$ )

1) Scientific Survey of the Tokara Islands, Report No. 7.

2) Contributions from the Seto Marine Biological Laboratory, No. 213.

3) Registered number of the Tokara collections deposited in the museum of the Seto Marine Biological Laboratory.

Pub1. Seto Mar. Biol. Lab., III (2), 1953. (Article 14) 
This clavulariid, together with the type species $C$. viridis $\mathrm{Q}$. et $\mathrm{G}$., have been fully described by the authors cited above. But for future reference some descriptions and illustrations of the present material may be given here supplementing those of previous authors mainly in regard to the spiculation and tentacle armature.

Numerous thickly-set polyps arising from a rather hard creeping stolon or platelike base contain all stages of development. The majority of polyps show on the average $15 \mathrm{~mm}$ long, with a diameter of $2-3 \mathrm{~mm}$ at base and $4-5 \mathrm{~mm}$ at the swollen upper portion; in the largest one, the anthostele measures $20 \mathrm{~mm}$ long, $2.5 \mathrm{~mm}$ across at base and $6 \mathrm{~mm}$ across at top, and the flexible anthocodia which is contracted is 5-6 mm long, including tentacles. A smallest one, which is a pear-shaped bud, is only $5 \mathrm{~mm}$ long and $4 \mathrm{~mm}$ wide at base.

Fully developed tentacles, when extended, are about $5 \mathrm{~mm}$ long and bear innummerable pinnules wholly covering the oral surface. In younger polyps less than $5 \mathrm{~mm}$ in total height, however, the tentacles are $2-2.5 \mathrm{~mm}$ long and bear two or three rows of pinnules on each side, with a slight bare streak between them, about 11 to 14 in a row (Fig. 1b,c); larger tentacles seem to bear 4 rows on each side, at least in the middle.

The spiculation of the polyp varies very markedly in different parts, as shown in Fig. 1a. Pinnules are wholly covered with the minute rodlets, extending to the base around the margin of tentacle on the aboral surface, not towards the oral surface. The median line of the aboral surface of tentacle is beset with longitudinally disposed, smooth or slightly warted rods or spindles larger than the preceding. At the base of tentacles, slender narrow spindles are arranged in regular 8 chevrons; between them there is no spicule. The introvertible neck portion of the anthocodia is thin-walled, semi-transparent and bears a few small spindles arranged horizontally. The stomodaeum is also provided with slender rodlets in the lower portion alone. The anthostele and stolon are quite firm, thickly covered with stouter large spindles and derivatives.

The measurements of these spicules in millimeters are as follows:-

(1) Pinnule......very minute finger-biscuit-like discs (Fig. $2 d-e$ ).

$$
0.028 \times 0.01 ; 0.03 \times 0.014 ; 0.04 \times 0.02 \text {. }
$$

(2) Base of pinnule around the margin of tentacle......minute rodlets (Fig. 2a-c). $0.04 \times 0.01 ; 0.07 \times 0.017$.

(3) Aboral side of tentacle axis......slightly roughened rodlets or small spindles (Fig. $2 f-h$ ).

$$
0.3 \times 0.04 ; 0.4 \times 0.05 ; 0.5 \times 0.09
$$

(4) Lower portion of stomodaeal wall......slender rodlets (Fig. $2 i-l$ ):

$$
0.06 \times 0.008 ; 0.085 \times 0.02 ; 0.16 \times 0.03 \text {. }
$$

(5) Crown of anthocodia......slender, smooth or warty spindles; bifurcate at one or 

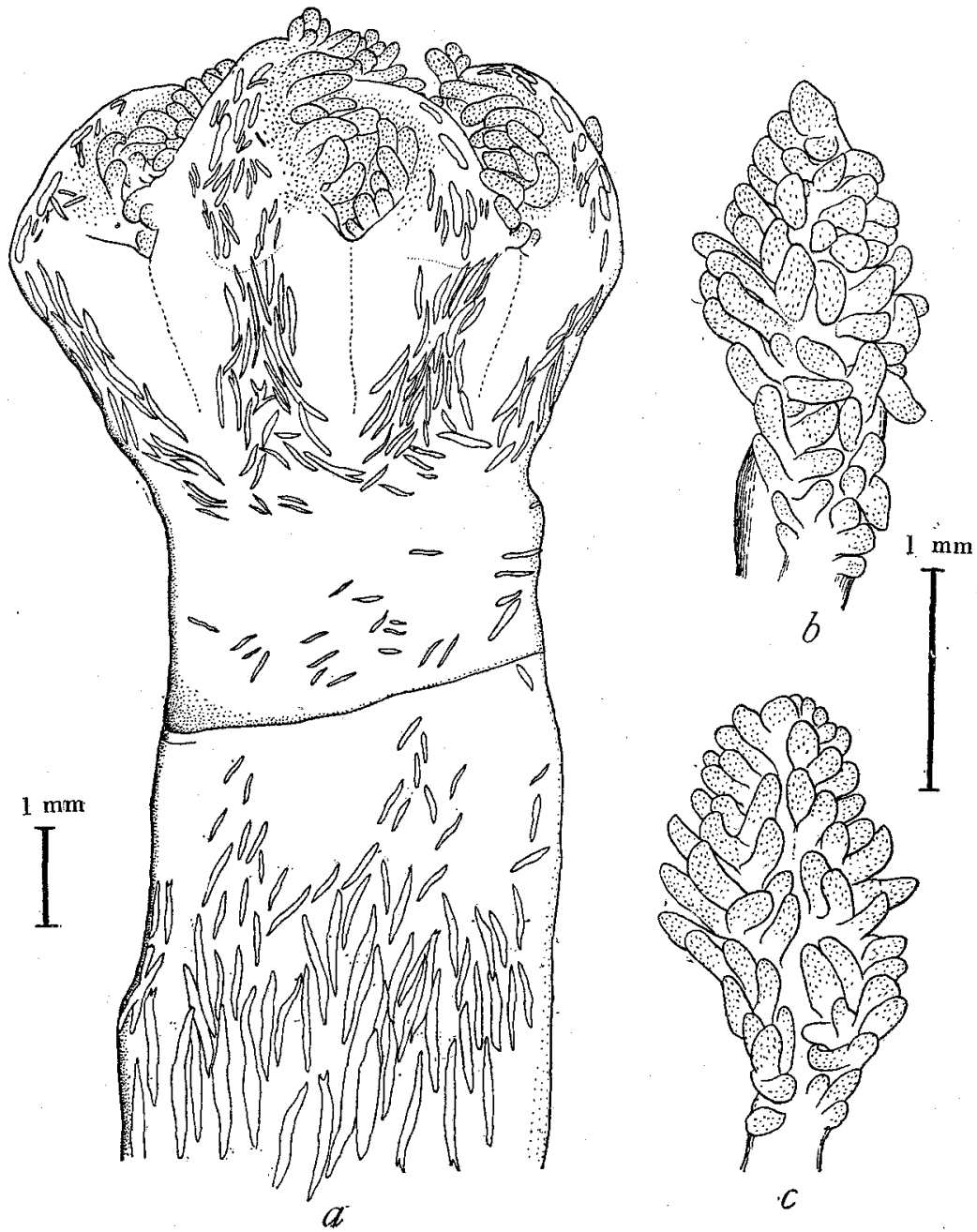

Fig. 1. Clavularia inflata SCHENK. $a$, Upper part of a polyp; $b, c$, inner view of tentacle in young polyps.

both ends, or with 3 or 4 branches (Fig. $2 m-p$ ).

$$
0.7 \times 0.07 ; 0.8 \times 0.07 ; 0.9 \times 0.07 \text {. }
$$

(6) Retrovertible neck portion of anthocodia...... slender, smooth or slightly warty spindles.

$$
0.4 \times 0.04 ; 0.6 \times 0.07 \text {. }
$$

(7) Anthostele......straight or slightly curved, large spindles with simple or compound warts; sometimes bifurcate at ends, or crosses (Fig. 2q).

$$
0.4 \times 0.07 ; 1.0 \times 0.15,1.35 \times 0.15 ; 1.45 \times 0.18 \text {. }
$$




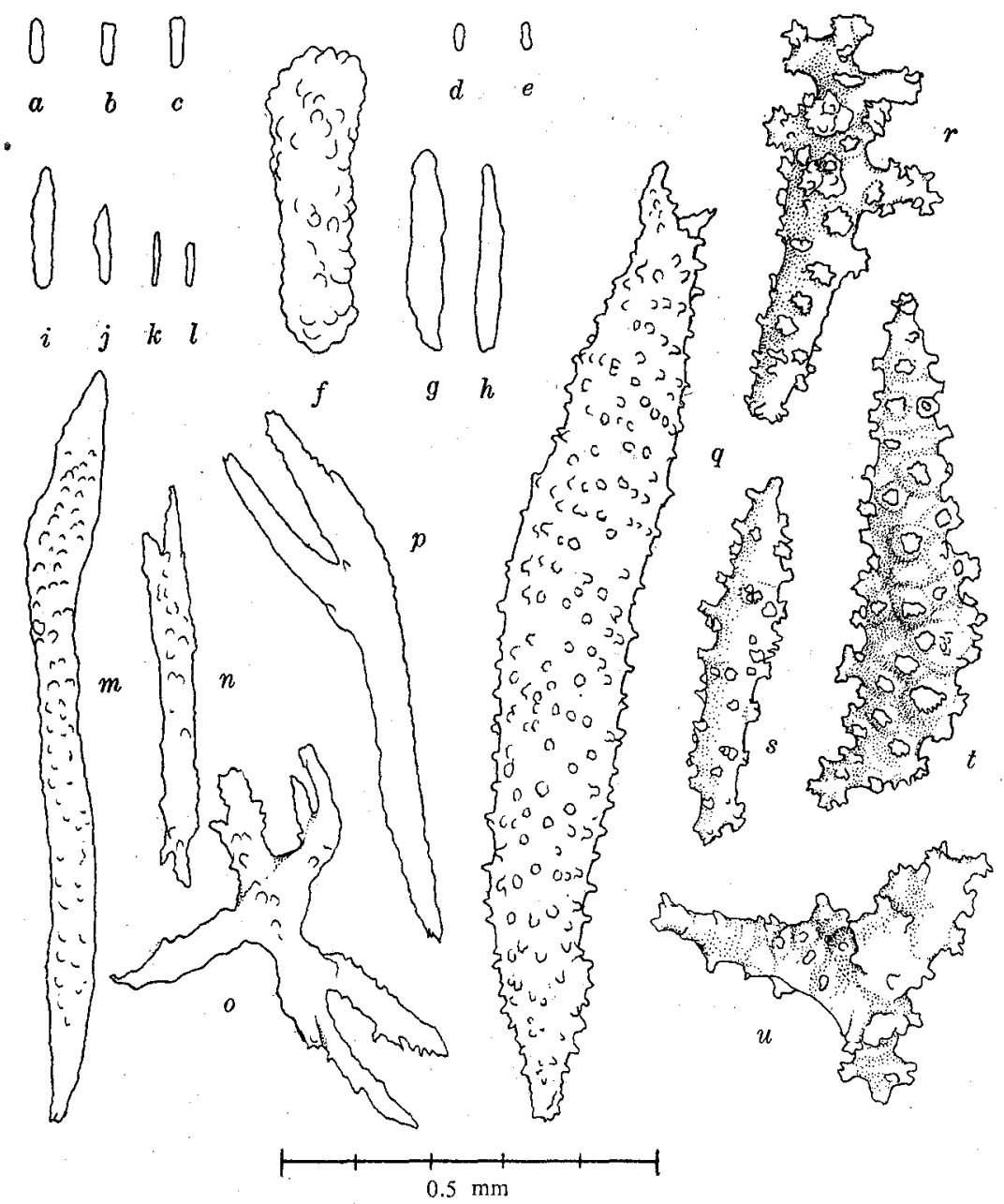

Fig. 2. Spicules of Clavularia inflata SCHENK. a-c, Spicules from base of pinnules on the aboral side of tentacle; $d-e$, from pinnules; $f-h$, from tentacle axis on the aboral side; $i-l$, from stomodaeal wall; $m-p$, from anthocodia; $q$, from anthostele; $r-u$, from stolon.

(8) Stolon......short, plump spindles, triradiates or their derivatives, covered with high compound warts (Fig. $2 \gamma-u$ ).

$$
0.38 \times 0.09 ; 0.6 \times 0.09 ; 0.7 \times 0.16 ; 0.8 \times 0.18 \text {. }
$$

Retractile anthocodia and tentacles are creamy white or light grey; in the living state any greenish tint is not observed. Upper portion of anthostele with sparsely set spicules is light grey, while its lower portion and stolon dirty brown. In some of the polyps, the coloration is not so distinctly differentiated.

Distribution. Luzon (Philippines), Ternate, Indonesia, Low Isles (Great Barrier 
Reef) and southern end of Formosa (unpublished).

Remarks. The Tokara specimens agree in detail with the Luzon specimens first described by MAY (1900) as a variety of C. inflata from Ternate. This variety should be included in the type species, since the specimens described by SCEENK may be indeed a young form, as inferred from his descriptions and figures. The generic name Hicksonia should be discarded according to the laws of priority, as pointed out by Molander (1929) and Roxas (1933 a), although Gohar (1940) emphasizes to retain the name as a unique group showing a close affinity with Tubipora. I can not share his opinion that "Hicksonia" (viridis and inflata) and Pachyclavularia (erecta etc.) are far apart from the ordinary clavulariid type in the presence of connecting tubes between the polyps.

As THOMSON and DEAN (1931) state, many of the polyps arise from the complicated, irregularly branched stolon which forms a network in different planes. This is apparently due to the unevenness of the surface of the substratum which is sandgrains deposited on the rock or a mass of sand-forming nests of a certain sedentary polychaete. Therefore, some of the stolons from which is borne a new polyp-bud, become to extend enough to touch the body wall of the adjoining polyp at various levels; its end is finally joined together with the latter but exists no organic connection between the polyps. As far as my observation goes, there is no evidence to show an actual intrusion of the internal canals of the stolon into the coelenteric cavily of the joined polyp (see also Hicrson, 1886, p. 323 and 1930, p. 242). Anyhow, tre stolon connecting one polyp with the middle of another, as seen in this species and $C$. viridis, is not essentially different from that in other ordinary stoloniferans.

\section{Alcyonacea \\ Family Alcyoniidae VerRILL \\ 2. Sarcophyton acutangulum (MARENZELLER)}

(Fig. $3 a-d$; Pl. VIII, Fig. 3)

For synonymy see KÜKENTHAL, 1910, p. 25 ; TIXIER-DURIVAULT, 1946, p. 81.

Jap. Name. Umitake (nom. nov.).

Material. One specimen from Nakano-sima, at low tide (TK. No. 57).

The speciman is small, showing a total height of $5 \mathrm{~cm}$ of which $4 \mathrm{~cm}$ is the stalk. The colony is quite mushroom-shaped, with a disc slightly folded at the margin and hollowed in the center, about $0.3 \times 0.4 \mathrm{~cm}$ in diamater. Some of the autozooids, mainly in the central portion, are fully expanded up to $1 \mathrm{~mm}$ in length. These are $0.5 \mathrm{~mm}$ apart and there is only one row of siphonozooids between two autozooids. The spicules 

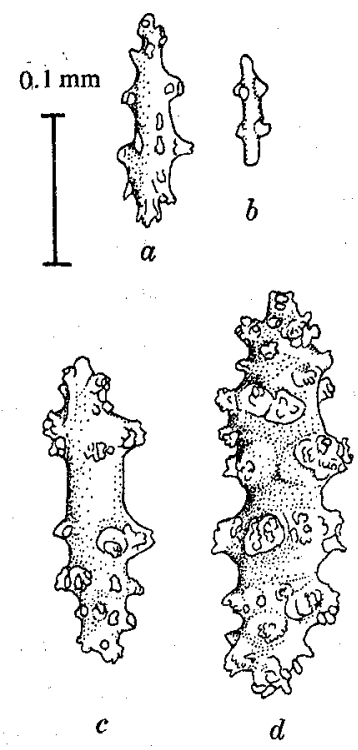

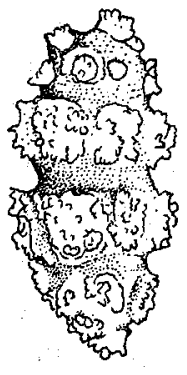

$e$

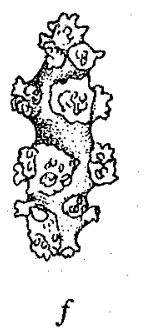

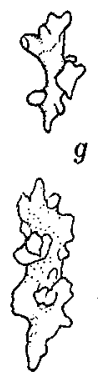
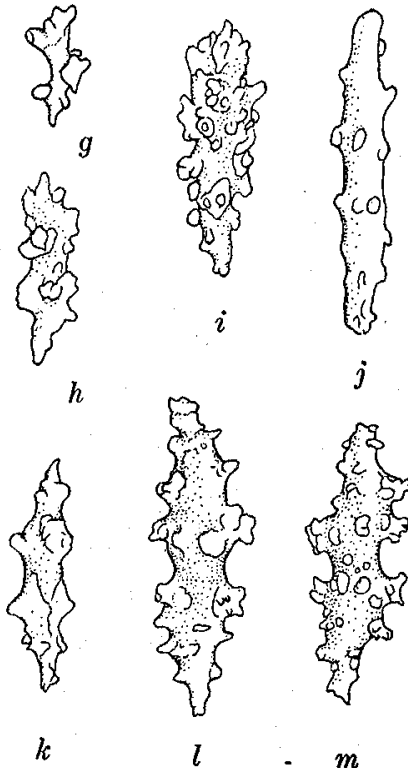

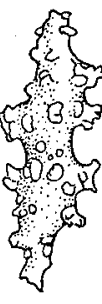

Fig. 3. Spicules of Sarcophyton acutangulum (MARENZELLER) $(a-d)$, S. trocheliophorum MARENZELLER $(e, f)$ and $S$. moseri ROXAS $(g-m)$. $g-j$, from disc interior and the rest from stalk interior.

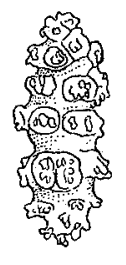

$a$

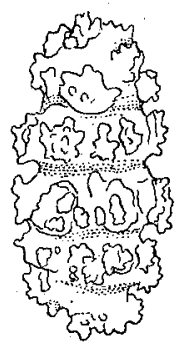

$b$

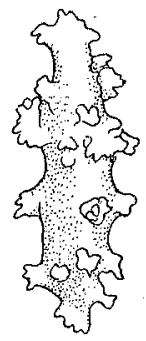

$c$

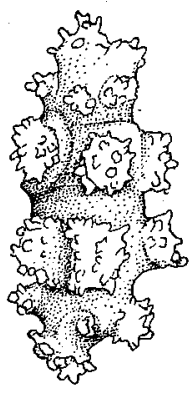

. $f$

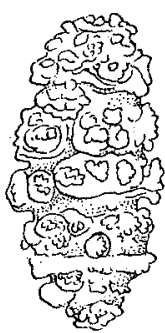

$d$

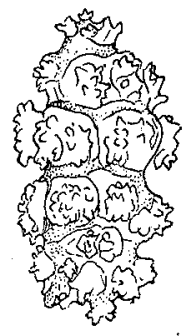

e
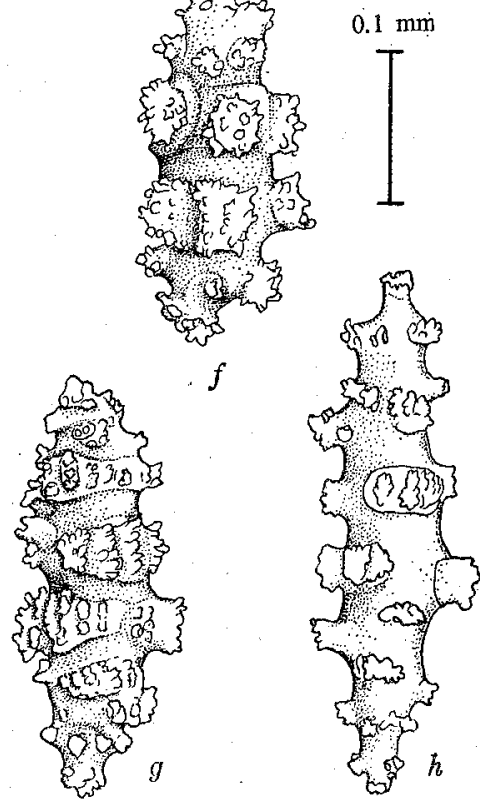

Fig. 4. Spicules of Lobophytum pauciflorum (EHRENBERG) (a-e) and L. crebriplicatum MARENZELLER $(f-h)$. $a$, Spicules from disc cortex; $b, c$, from stalk cortex; $d$, from disc coenenchyme; $e$ - $g$, from stalk coenenchyme; $h$, from disc coenenchyme. 
of stalk interior are warty spindles, covered with 2-6 whorls of compound warts, the number of which increases in larger spicules.

Distribution. Red Sea, Ceylon, Maldives, north and southwest Australia, Tonga, Fiji Islands, Indonesia.

The distribution of this species further extends as far north as the Kii coast of middle Jappan, as occasionally found there.

\section{Sarcophyton trocheliophorum MARENZELLER}

(Fig. $3 e-f$; P1. VIII, Fig. 4)

For synonymy see KüKENTHAL, 1910, p. 18; TIXIER-DURIVAULT, 1946, p. 349.

Jap. Name. Hidaberi-umitake (nom. nov.).

Material. Two specimens from Nakano-sima, at low tide (TK. No. 58).

Two subequal colonies, greenish-brown in colour, have the disc much convoluted at the margin into about 10 main thick folds, the largest one measures a disc $67 \mathrm{~mm}$ in maximum diameter and a stalk $30 \mathrm{~mm}$ high on one side and $55 \mathrm{~mm}$ in maximum diameter. Between two autozooids about $0.8 \mathrm{~mm}$ apart, about 2 or 3 tiny siphonozooids are found; yet more numerous may be found in larger colonies. There are up to 15 autozooids to a centimeter at the margin. The spicules of the stalk are mostly roundended, barrel-shaped one, with 2 broad median whorls and 2 terminal clusters of very large compound warts, on the average $0.24 \times 0.1 \mathrm{~mm}$ in size.

Distribution. Widespread in the warm Indo-West Pacific area.

\section{Sarcophyton moseri ROXAS}

(Fig. 3 g-m; Pl. VIII, Fig. 5)

Sarcophyton moseri ROXAS, 1932, p. 80, pl. I, fig. 2a-e; ROXAS, 1933b, p. 378, pl. I, fig. 6. Sarcophytum moseri TIXIER-DURIVAULT, 1946, p. 169.

Jap. Name. Usuberi-umitake (nom. nov.).

Material. One specimen from Nakano-sima, at low tide (TK. No. 59).

The specimen agrees well with the Philippine specimen of this species. The disc, about $57 \times 70 \mathrm{~mm}$, slightly projects from the stalk, with about 7 low main folds around the broadly depressed central portion. The stalk is rather short and broad, being about $30 \mathrm{~mm}$ high and $53 \mathrm{~mm}$ wide at base. The folded rim of the disc is rather thin, about $4 \mathrm{~mm}$ in thickness everywhere. There is only one row of siphonozooids between two autozooids, less than $0.5 \mathrm{~mm}$ apart. The spicules of the disc surface are small rods or clubs with irregularly placed simple warts and $0.08-0.2 \mathrm{~mm}$ long. In the stalk interior are small spindles with small irregularly placed warts and pointed at both ends, about 
$0.15-0.2 \mathrm{~mm}$ long. Greenish cream in colour.

Distribution. Mindoro (Philippines), Détroit de la Sonde.

\section{Lobophytum pauciflorum (EHRENBERG)}

(Fig. 4 a-e; P1. VIII, Fig. 6)

Lobularia pauciflora EHRENBERG, 1834, p. 58.

Sarcophytum pauciflorum KLUNZINGER, 1877, p. 29, pl. II, fig. 2.

Lobophytum pauciflorum var. validum MARENZELLER, 1886, p. 366, pl. IX, fig. 12; MOSER, 1919, p. 92, fig. 20; MACFADYEN, 1936, p. 48.

Lobophytum pauciflorum HICKSON \& HILES, 1900, p. 505; MOSER, 1919, p. 86, fig. 19, pl. V, figs. 3-6; THOMSON \& DEAN, 1931, p. 69; ROXAS, 1933b, p. 367; MACFADYEN, 1936, p. 47, pl. III, fig. 1 .

Lobophytum candelabrum ROULE, 1908, p. 177; THOMSON \& DEAN, 1931, p. 65.

Jap. Name. Ibo-unetake (nom. nov.).

Material. Two fragments of colonies from Takara-zima, at low tide (TK. No. 60).

Both colonies, about $11 \mathrm{~cm}$ in maximum diameter, agree well with MARENZELLER's

var. validum. But as suggested by RoxAs, this may be merely a developmental variety. The colony is carpet-like, with a sterile stalk broader than high; the texture is very firm and the colour is uniformly dark grey. The disc, which is sharply defined from the sterile stalk, bears a lot of high finger-like lobes all over the surface, forming somewhat parallel rows. These lobes are upright and roundly tipped, on the average $6 \mathrm{~mm}$ thick and 10-12 $\mathrm{mm}$ high; some low secondary lobes occur on the slightly ridged margin. The autozooids are distinct, about $2 \mathrm{~mm}$ apart on the lobes, but rather scarce towards the disc between lobes. The siphonozooids are smaller but visible, about five between two autozooids on the lobes.

The cortical spicules of the lobes are mostly small spindles, about $0.08 \times 0.02 \mathrm{~mm}$ to $0.2 \times 0.07 \mathrm{~mm}$. Those in the sterile stalk include larger, blunt-ended, barrel-like spicules, about $0.18 \times 0.08 \mathrm{~mm}$ to $0.23 \times 0.09 \mathrm{~mm}$ and slender spindles, about $0.14 \times 0.05$ $\mathrm{mm}$ to $0.22 \times 0.07 \mathrm{~mm}$. In the coenenchyme of lobes and stalk are mostly barrel-shaped spicules with usually 4 to 6 distinct whorls of heavy warts; they measure $0.18 \times 0.09$, $0.2 \times 0.1,0.23 \times 0.09,0.24 \times 0.09$ in millimeters. In larger barrels, the space between warty whorls are usually narrow, and in smaller and longer spindles are warts often in whorls or irregularly scattered.

Distribution. Widespread in the warm Indo-West Pacific area.

\section{Lobophytum crebriplicatum MARENZELLER}

(Fig. $4 f-h$; PI. VIII, Fig. 7)

Lobophytum crebriplicatum MARENZELLER, 1886, p. 362, pl. IX, fig. 7 ; MOSER, 1919, p. 79, 
fig. 15; ROXAS, 1933b, p. 362 ; MACFADYEN, 1936, p. 45.

Jap. Name. Naga-unetake (nom. nov.).

Material. Two specimens from Nakano-sima, at low tide (TK. No. 61).

A large incomplete colony, with a total height of $7.5 \mathrm{~cm}$ and a capitulum of $7 \times 9$ $\mathrm{cm}$ in diameter, only half of which remains. The capitular disc hollowed in the center, is covered with high, leaf-like folds, about $5 \mathrm{~mm}$ thick and about $15 \mathrm{~mm}$ high, whose apices are generally smooth but often slightly notched one or two times, though not deeply cleft. These folds extend radially towards the center where is not folded; the longest one extends up to $6 \mathrm{~cm}$. The wall of the stalk is for the most part creamy grey coloured and longitudinally striated, but transversely corrugated near the base where it is brownish.

The autozooids are large, 1-2 $\mathrm{mm}$ apart and between these lie the closely set siphonozooids, about 1 or 2 between two autozooids on the lobes, but 2 or 3 on the sides. The spicules of the stalk interior are spindles with broad compound warts in more than 4 whorls, up to $0.25-0.29 \mathrm{~mm}$ long and $0.075 \mathrm{~mm}$ wide. Those in the disc interior are as a whole longer spindles with small compound warts, up to $0.35 \mathrm{~mm}$ long and $0.07-0.08 \mathrm{~mm}$ wide. Compared with those in the preceding species, the spicules are longer and more slender, with widely spaced warts, not forming so distinct whorls. Another smaller colony, about $3 \mathrm{~cm}$ high and $5.5 \mathrm{~cm}$ in longest diameter (Pl. VIII, Fig. 7), shows the same appearance and spiculation, though the colouration is lighter.

Distribution. Tonga Island, Low Isles and Madagascar (after MOLANDER, 1921).

\section{Microspicularia sphaeroides n. sp.}

(Fig. 5; Pl. VIII, Figs. 8-10)

Jap. Name. Nôtosaka (nom. nov.).

Material. Holotype (S. M. B. L. No. 126) and 5 paratypes (TK. No. 62) from Takara-zima, at low tide.

These six colonies with a cerebriform appearance clearly belong to the genus Microspicularia, but cannot be referred to any of the described species. Recently, Tixier-Durivault $(1943-44,1948)$ has comprehensively studied the encrusting $A l$ cyonium-like group with small capstan-like and more tiny disc-shaped sclerites, which has been confused with the typical Alcyonium. Unfortunately, for this group she revived the old name Lobularia which had already been abandoned as a synonym of Alcyonium (the type of LAMARCK, L. digitata, is a species of the typical Alcyonium), despite that a revised opinion on the nomenclature was expressed by MACFADYEN (1936) after her Siboga report. Hence I am now using the name Microspicularia of MACFADYEN instead of Lobularia.

All the colonies are rather small, roughly round to oval in outline, up to $45 \mathrm{~mm}$ 
in maximum diameter, and covered wholly with 10-15 compressed round lobes which are from $5 \mathrm{~mm}$ to $7 \mathrm{~mm}$ high and from about $4 \mathrm{~mm}$ to $7 \mathrm{~mm}$ wide; some of the lobes are not distinctly divided but become lengthened with 2 or 3 slight notches at the apex. The sterile stalk attached to the dead coral block is not wider than the capitulum, and is delimited by the broadening of marginal lobes from the latter; its height is only $5 \mathrm{~mm}$ anywhere.

The polyps are small, $0.7-0.9 \mathrm{~mm}$ in diameter, closely set and count about 7 to a length of $5 \mathrm{~mm}$. These are completely retractile, but some of them especially on
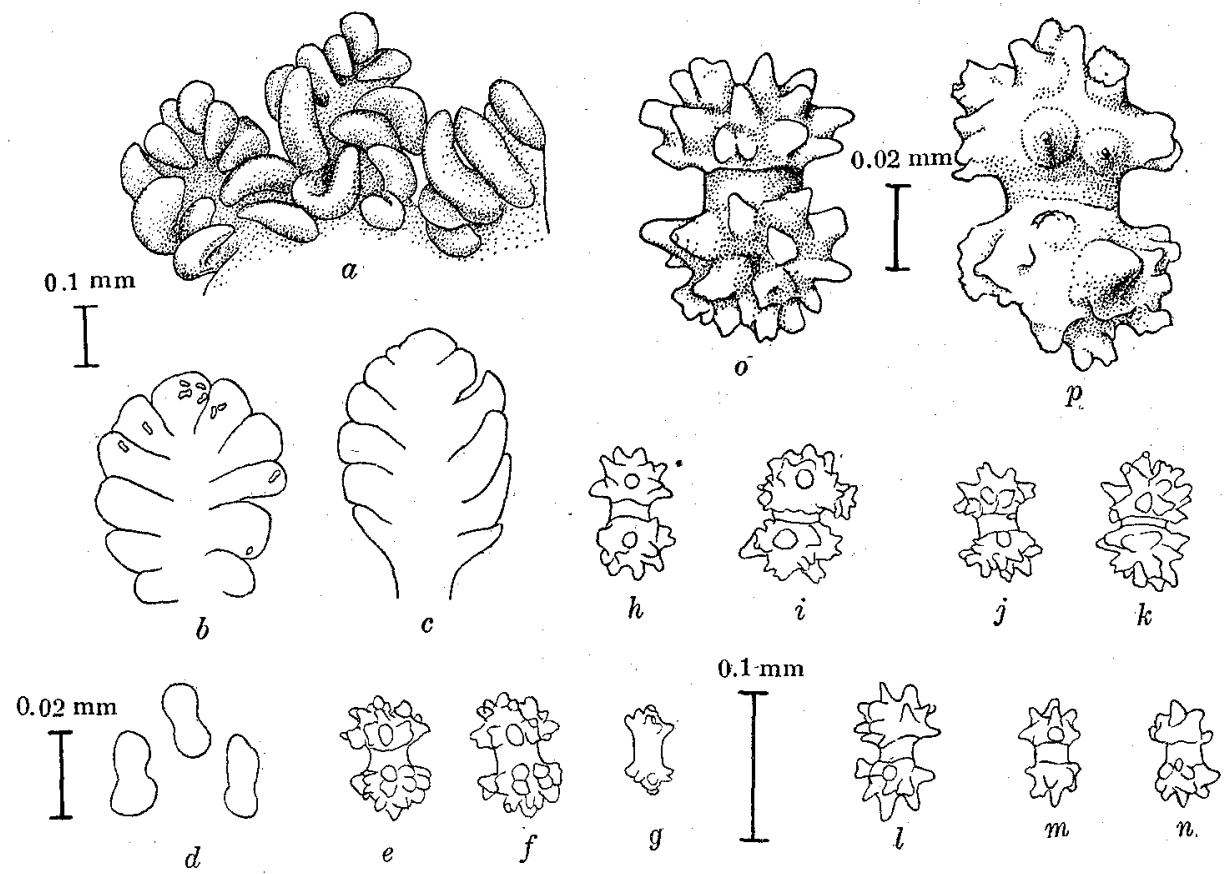

Fig. 5. Tentacles and spicules of Microspicularis sphaeroides n. sp. a, Aboral view of three tentacles; $b, c$, tentacle; $d$, spicules from pinnules; $e-g$, from cortex of lobes; $h-i$, from cortex of base; $j-k$, from coenenchyme of base; $l-n$, from coenenchyme of lobes; $o$, from coenenchyme of base, much enlarged; $p$, from cortex of lobes, much enlarged.

the valleys remain fully expanded. The tentacles, about $0.3 \mathrm{~mm}$ long, bear five broad pinnules on each side; most of them are apparently devoid of spicules, but a few very minute spicules may be found only at the ends of pinnules; these spicules are finger-biscuit-shaped, reaching $0.018 \times 0.008 \mathrm{~mm}$ in size. All the spicules contained in the cortex and coenenchyme are almost similar to one another in shape as well as in size. They are all capstans with roundly pointed warts at both ends and a median narrow waist, which are as a whole much smaller than those found in other species, 
as follows:

Cortical spicules of lobes $\cdots \cdots \cdots \cdots \cdots . .0 .05 \times 0.04 \mathrm{~mm} ; 0.07 \times 0.04 \mathrm{~mm}$.

Coenenchymal spicules of lobes $\cdots . .0 .05 \times 0.04 \mathrm{~mm} ; 0.07 \times 0.04 \mathrm{~mm}$.

Cortical spicules of base $\cdots \ldots \ldots \ldots . . .0 .07 \times 0.04 \mathrm{~mm} ; 0.08 \times 0.05 \mathrm{~mm}$.

Coenenchymal spicules of base $\cdots . .0 .08 \times 0.05 \mathrm{~mm} ; 0.085 \times 0.05 \mathrm{~mm}$.

No finger-biscuit-like forms do exist in the tissue excepting tentacles.

The colonies in spirit are uniformly greyish white. According to Dr. Tokıora's field-note, their expanded colonies under the water are brownish, but change suddenly to white when exposed.

Remarks. This species at a glance resembles closely $M$. sphaerophora (EHRENBERG) amongst all of the described species, but it is distinguishable from the latter in the smallness and uniformity of all spicules and in the polyps almost devoid of spicules.

\section{COENOTHECALIA}

\section{Family Helioporidae Moseley \\ 8. Heliopora coerulea (PALlas)}

Heliopora coerulea EGUCHI, 1948, p. 362, pl, 60, figs. 3, 4,6 (with synonymy).

Jap. Name. Aosango.

Material. A dead fragment of this blue coral (TK. No. 63) was found as mingled with coral blocks and sands at Nakano-sima. This species is. known to occur in the Ryukyu Islands in both the recent and fossil forms, as far south as the South Sea Islands and the Indian Ocean, where it is very plentiful in coral reefs. But Dr. TokiokA did not find it there in the living state.

\section{REFERENCES}

EGUCHI, M. 1948. Fossil Helioporidae from Japan and the South Sea Islands. Jour. Paleont., vol. 22 , no. 3 , pp. $362-364$, pl. 60 .

EHRENBERG, C. G. 1834. Corallenthiere des Rothen Meeres. Sitzb. K. Akad. Wiss. Berlin. (cited from KLUNZINGER).

GOHAR, H. A. F. 1940. A revision of some genera of the Stolonifera. Publ. Mar. Biol. Stat. Ghardaqa (Red Sea), no. 3, pp. 1-23, 1 pl.

HICKSON, S. J. 1886. Preliminary notes on certain zoological observations made at Talisse Island, North Celebes. Proc. Roy. Soc. London, vol. 40, pp. 322-325.

1930. On the classification of the Alcyonaria. Proc. Zool. Soc. London, 1930, pp. 229-252.

\& HILES, I. L. 1900. The Stolonifera and Alcyonacea collected by Dr. Willey in New Britain, etc. Willey's Zool. Res., pt. IV, pp. 493-508, pls. L-LI.

KLUNZINGER, C. B. 1877. Korallthiere des Rothen Meeres. Erster Theil: Die Alcyonarien und Malacodermen. Berlin. vii+94 pp., 7 pls. 
KÜKENTHAL, W. 1910. Alcyonaria. Die Fauna Südwest-Australiens, Bd. 3, Lief. 1, pp. 1-108, pls. I-IV.

MACFADYEN, L. M. I. 1936. Alcyonaria (Stolonifera, Alcyonacea, Telestacea and Gorgonacea). Great Barr. Reef Exped., Sci. Rep., vol. 5, no. 2, pp. 19-71, pls. I-V.

MARENZELLER, E. von 1886. Ueber die Sarcophytum benannten Alcyoniiden. Zool. Jahrb., Abt. Syst., Bd. 1, Ht. 2, pp. 341-368, pl. IX.

MAY, W. 1900. Beiträge zur Systematik und Chorologie der Alcyonaceen. Jena. Z. Naturw., Bd. 33, pp. 1-180, pls. I-V.

MOLANDER, A. R. 1921. Alcyonarien von Madagaskar. Ark. Zool., Bd. 14, no. 2, pp. 1-13.

- 1929. Die Octactiniarien. Further Zool. Res. Swedish Antarctic Exped., vol. 2, no. 2, pp. 1-86, pls. I-IV.

MOSER, J. 1919. Beiträge zu einer Revision der Alcyonarien. I. Die Gattungen Sarcophyton Lesson und Lobophytum Marenzeller. Mitt. Zool. Mus. Berlin, Bd. 9, pp. 219-293, pls. V-VI.

ROUle, L. 1908. Alcyonaires d' Amboine. Rev. Suisse Zool. Genève, t. 16, pp. 161-194, pls. VI-VIII.

RoXAS, H. A. 1932. Two new species of Sarcophyton Less, from the Philippines. Univ. Phil. Nat. Appl. Sci. Bull., vol. 4, no, 1, pp. 73-81, pl. I.

- 1933a. Philippine Alcyonaria. The families Cornulariidae and Xeniidae. Phil. J. Sci., vol. 50, no. 1, pp. 49-110, pls. I-IV.

1933b. Philippine Alcyonaria, II. The families Alcyoniidae and Nephthyidae. Ibid., vol. 50 , no. 4 , pp. $345-470$, pls. I-V.

SCHENK, A, 1896. Clavulariiden, Xeniiden und Alcyoniiden von Ternate. Abhandl. Senckenb. Naturf. Ges., Bd. 23, pp. 41-80, pls. II-IV:

THOMSON, J. A. \& DEAN, L. M. I. 1931. The Alcyonacea of the Siboga Expedition, with an appendam to the Gorgonacea. Siboga-Expeditie, mon. 13d, livr. 115, 227 pp., 28 pls.

Tixier-DuRivault, A. 1943-44. Les Alcyonaires du Muséum: I. Famille des Alcyoniidae. 1. Genre Lobularia. Bull. Mus. Nat. Hist. Nat. Paris, 2 S., t. 15 , no. 6 , pp. 437-443; t. 16, no. 3 , pp. $183-190$; no. 5 , pp. $339-345$; no. 6 , pp. 476-482. 1946. Les Alcyonaires du Muséum: I. Famille des Alcyoniidae. 3. Genre Sarcophytum. Ibid., t. 18 , no. 1 , pp. $80-86$; no. 2 , pp. $165-171$; no. 4 , pp. 348-354. 1948. Révision de la famille des Alcyoniidae. 1. Le genre Lobularia Ehrbg. (nec

Lamarck). Mém. Mus. Nat. Hist. Nat. Paris, N. S., t. 23, fasc. 1, pp. 1-256.

\section{EXPLANATION OF PLATE VIII}

(All the photographs taken in spirit by the aid of Mr. I. YAMAZI.)

Figs. 1, 2. Clavularia inflata SCHENK. Nakano-sima.

Fig. 3. Sarcophyton acutangulum (MARENZELIER). Nakano-sima.

Fig. 4. Sarcophyton trocheliophorum MARENZELLER. Nakano-sima.

Fig. 5. Sarcophyton moseri RoxAs. Nakano-sima.

Fig. 6. Lobophytum pauciflorum (EHRENBERG). Takara-zima.

Fig. 7. Lobophytum crebriplicatum MARENZELLER. Nakano-sima.

Fig. 8. Microspicularia sphaeroides n. sp. Takara-zima. (Holotype)

Figs. 9, 10. Microspicularia sphaeroides n. sp. Takara-zima. (Paratypes)

(Figs. 1, 2, 8-10, $\times 1$; Figs. 3-6, $\times 2 / 3$ ) 


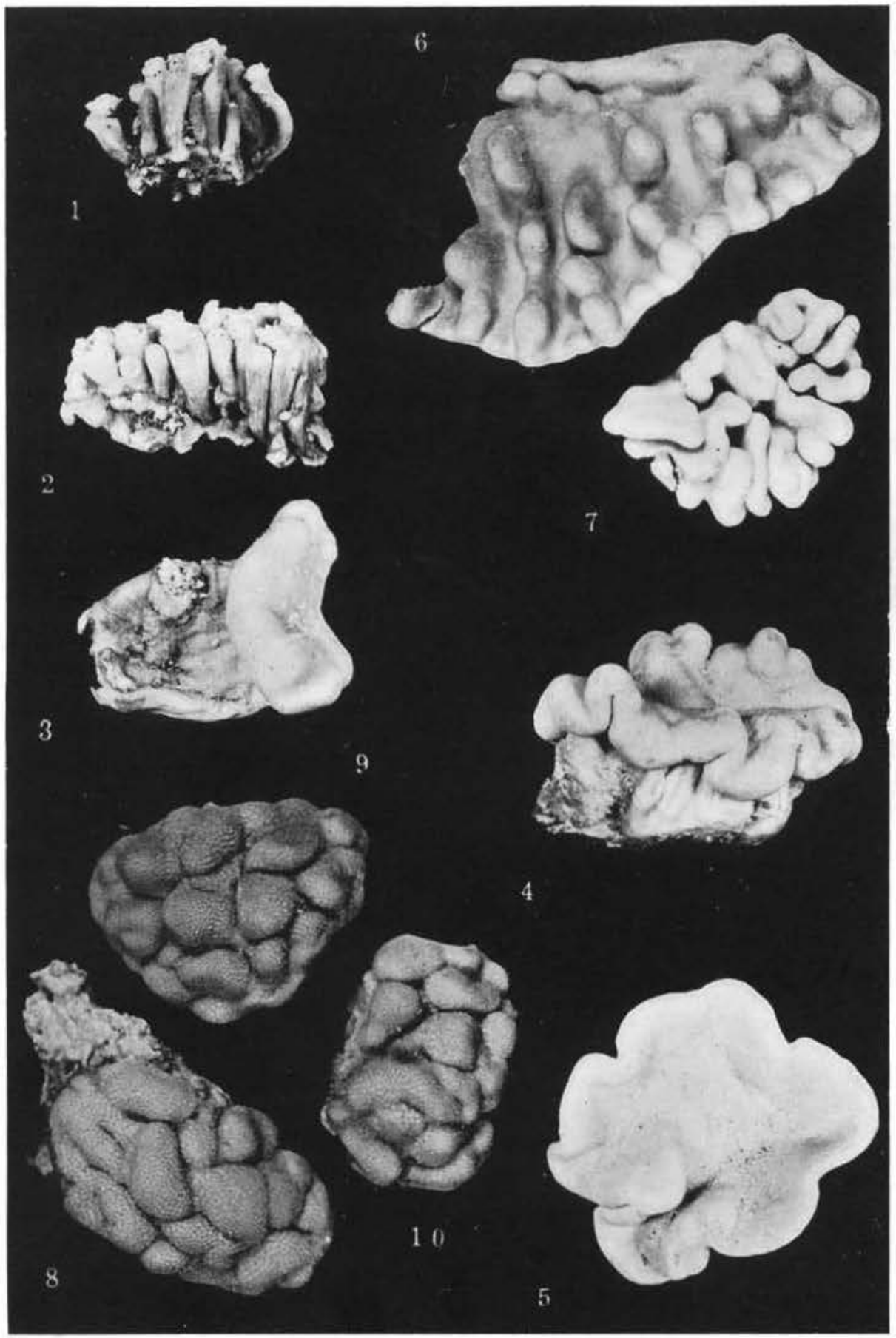

H. Utinomi : InVERTEBrate Fauna of THE Tokara Islands, VI. 